\title{
Weather Condition, Seasonal Variation and Ball Development Pattern in Relation to Rice False Smut Disease in Bangladesh
}

\author{
B Nessa ${ }^{1,2 *}$, M U Salam³, A H M M Haque ${ }^{1}$, M A Kashem4, and MS Kabir²
}

\begin{abstract}
Rice false smut (RFSm) is an international disease. The effect of the disease has become seriously evident in Bangladesh since 2010. The disease is predominant in the country in the 'T. Aman' rice growing season. Its occurrence in other rice growing seasons not well studied and recorded. Information on driving weather variable(s) causing the disease epidemic is scanty and not groundtruthed. This study, conducted in the experimental farm of the Bangladesh Rice Research Institute, Gazipur, Bangladesh, attempted to fill those information gaps. The association of disease incidence and weather parameters such as relative humidity, cloud hour and rainfall, was inconsistence except for the daily average temperature. High disease incidence occurred when the average temperature during panicle emergence period ranged between $22-27^{\circ} \mathrm{C}$; any temperature below or above the range linearly decreased the disease incidence. RFSm disease was recorded in the study area in all the months, except for in February and March. The distribution in the incidence of disease in the three rice growing seasons followed the order of 'T. Aman' > 'Aus' > 'Boro'; it was six times less in 'Aus' and eight times less in 'Boro' season, compared to 'T. Aman' season. New balls formed on infected panicles in batch by batch. High number of such batches formed in 'T. Aman' season. The final status of the disease in an infected crop was the accumulation of incidence of the disease in each batch. This study provided key epidemiology on the development of RFSm in nature and it is concluded such information on the disease under local conditions would be the key to designing management options.
\end{abstract}

Key words: Rice false smut, disease incidence, epidemic, pattern of smut ball development, weather variables, seasonal variation, Ustilaginoidea virens, Villosiclava virens

\section{INTRODUCTION}

False smut (RFSm) (anamorph: Ustilaginoidea virens (Cooke) Takah.; teleomorph: Villosiclava virens (Nakata) E. Tanaka \& C. Tanaka) is an international disease of rice. Once treated as 'minor' disease (Webster and Gunnell, 1992), its status has changed with widespread reports in almost all the rice growing countries of the globe (Nessa et al. 2015a; Nessa, 2017). With increasing incidence being reported from farmers' fields since early 2010s, RFSm is now an emerging disease in Bangladesh (Dhaka Tribune, 2013). Kabir et al. (2015) mention that the adoption of 'BRRI dhan49', a promising genotype for 'T. Aman' season in Bangladesh, is being seriously hindered by this disease.

RFSm is an inflorescence disease. The symptom of the disease only appears when rice crop is in flowering stage. The fungus infects individual spikelets and replaces the seed with a large velvety orange or greenish-black ball (Nessa, 2017), commonly known as 'smut ball'. It has been recorded in the pattern of aggregation in spaces in most of the fields (Nessa et al. 2015b). On infected panicles, there is about $60 \%$ probability that maximum of four smut balls will appear and about $88 \%$ of those balls will locate in the mid to basal part (Nessa

\footnotetext{
${ }^{1}$ Department of Plant Pathology and Seed Science, Sylhet Agricultural University, Sylhet 3100, Bangladesh; ${ }^{2}$ Bangladesh Rice Research Institute (BRRI), Gazipur 1701, Bangladesh; and 'Freelance Consultant (Agricultural Research, Development and Modelling), C1 (Dishari-10), BRRI Residential Area, BRRI, Gazipur 1701, and ${ }^{4}$ Department of Soil Science, Sylhet Agricultural University, Sylhet 3100, *Corresponding author's E-mail: runu.brri@yahoo.com
} 
et al. 2016). Further, the grain quality issues in relation to RFSm have been studied (Nessa et al. 2018). The appreance of the disease at different flowering time differs (Nessa et al. 2015c). Research indicates the infection is likely to onset one or two or even three weeks earlier to the appearance of smut balls (Li et al. 2013; Jia et al. 2014). The association of weather variables during infection stage to the incidence of RFSm has not been well documented.

Rice cultivation in Bangladesh is highly intensive. The crop is grown in three seasons within a year: in winter (named 'Boro'), early monsoon (named 'Aus') and late monsoon (named 'Transplanted Aman or T. Aman'). The RFSm is the disease of 'T. Aman' rice in Bangladesh (BRRI, 2013) and part of India (Shetty and Shetty, 1985). However, there are undocumented reports of its sporadic incidence in 'Aus' and 'Boro' rice. While, the seasonal incidence of RFSm is qualitatively sketched by Bangladesh Rice Research Institute (BRRI, 2013), it has not been quantified yet. Furthermore, the epidemiological aspects explaining why the disease is dominant in a particular season and not in others remained unexplored. This information is vital to understand if the status of the disease could change in non-dominating seasons especially in the scenarios of climate change or climate variability.

With the above background, this research was undertaken to investigate the weather driver(s) during panicle emergence causing the disease epidemic, the relative incidence of false smut disease in three rice growing seasons of Bangladesh and the sequence of infection and/or disease appearance in infected panicles,.

\section{MATERIALS AND METHODS}

The study was carried out in the experimental farm of the Bangladesh Rice Research Institute (BRRI), Gazipur, Bangladesh, located at 235'
$\mathrm{N}$ latitude, $90^{\circ} 2^{\prime} \mathrm{E}$ longitude. This farm has built up as an intensive rice-ecosystem in the last 40 years by growing three rice crops annually in 192 fields spread over 40.48 hectare area (Nessa, 2017). The recorded rice false smut disease incidence (DI) was calculated as follows.

DI $=[($ Number of diseased panicles $) /$ (total number of panicles) $] \times 100$

\section{Data for relating disease incidence and weather variables}

The disease incidence of 46 fields in the study area was monitored at different time of the year during 2014, 2015 and 2016. Historically, 16 fields had high, 12 had moderate and 18 had low disease pressure. Disease incidence and panicle emergence time (50\% flowering) in those fields were recorded.

\section{Monitoring of the disease incidence in 'Boro', 'Aus' and 'T. Aman' rice}

The disease incidence was visually monitored weekly at the ripening stage (post-panicle emergence to late maturity) of rice crops during September 2014 through to September 2017 by scouting across the fields in the experimental farm of the Bangladesh Rice Research Institute (BRRI), Gazipur, Bangladesh, located at $23^{\circ} 59^{\prime} \mathrm{N}$ latitude, $90^{\circ} 24^{\prime}$ E longitude. The RFSm incidence was assessed in the fields which showed apparently high infection. The sample size (number of panicles) varied between 158 and 9648; the size depended on the prevalence of the disease (Table 1).

\section{Batch by batch smut ball formation}

The sequence of new smut ball formation (each sequence was termed as a 'batch') was studied during T. Aman 2015. The test variety 'BRRI dhan49' was transplanted on 19 July in a $30.5 \mathrm{~m} \times 2.5 \mathrm{~m}$ section of a field in the 'West Byed' section of the experimental site where the disease pressure was historically high. The plot was sub-divided into three sections, each represented a replication. The hills in the main 
Table 1. The sampling field and sample size (number of panicles) for assessing the incidence of rice false smut disease in the experimental site during three rice seasons in three years.

\begin{tabular}{llccc}
\hline Season & Year & Location & Field & Number of panicles assessed \\
\hline Boro & 2015 & East Byed & 4 & 302 \\
& 2016 & East Byed & 3 & 158 \\
\multirow{3}{*}{ Aus } & 2017 & East Byed & 3 & 336 \\
& 2015 & West Byed & 3 & 158 \\
\multirow{2}{*}{ T. Aman } & 2016 & West Byed & 3 & 261 \\
& 2017 & East Byed & 3 & 4392 \\
& 2014 & West Byed & 6 & 9648 \\
\end{tabular}

crops were harvested at maturity by manually cutting the tillers at $40-60 \mathrm{~cm}$ height and then the ratoons (regenerated tillers) were allowed to grow. No additional crop management practices were applied for ratoons, except for maintaining a water level of 2 to $3 \mathrm{~cm}$ through irrigation. The new smut balls, by batches, were counted on ratoons as those appeared beginning on 17 November and ending on 5 January (2016). Altogether, 8 batches were recorded and the number of panicles observed was $485,464,407,539,412,431,501$, and 573, respectively for batches 1 through to 8 .

In addition, during 'Aus' 2017, the sequence of new smut ball formation was monitored on testing breeding lines in the research field of Biotechnology Division in the experimental site. This location was purposively selected as the disease pressure had been historically high. This monitoring was carried out weekly during August to September. On each visit, about 10000 panicles were inspected.

\section{Statistical analysis}

For developing the relationship between weather variables and RFSm incidence, daily weather data from Plant Physiology Division of BRRI were collected. Moving average (the day and post two days of panicle emergence) of each of the four weather variables, average temperature ${ }^{\circ} \mathrm{C}$, relative humidity $(\%)$, cloud hour and total rainfall $(\mathrm{mm})$, were summarized for each data-point (46 samples). The relationship between each of the weather variables and the disease incidence was analysed through $X: Y$ graph. Data from the high disease pressure field are presented in this manuscript.

The observation of the disease incidence was expressed as the mean and 95\% confidence intervals (CI) of the fields assessed. The results of the batch-by-batch smut ball formation were summarized in two ways: (i) the incidence of the disease as mean and $95 \% \mathrm{CI}$ of three replicates; and (ii) cumulative percentage of disease incidence at three panicle emergence times - 15 November, 30 November and 15 December. The CI was calculated using the inbuilt formula in MS Excel.

\section{RESULTS}

\section{Relationship between weather variables and the disease incidence during panicle emergence}

The association of four weather variables during $50 \%$ panicle emergence and rice false smut disease incidence (DI) was inconsistent except for daily average temperature (Fig. 1a). For example, high DI was recorded in the range of relative humidity (RH) of 64 to $98 \%$; side by side, low DI occurred in the range of $\mathrm{RH}$ of 69 to $91 \%$ (Fig. 1b). On cloudiness status, high DI was recorded when cloud-days ranged from 2 to 10 hours; whereas, low DI occurred at 4-8 hours cloud-days (Fig. 1c). Surprisingly, very high and very low disease was observed when crops received nil rains (Fig. 1d). 

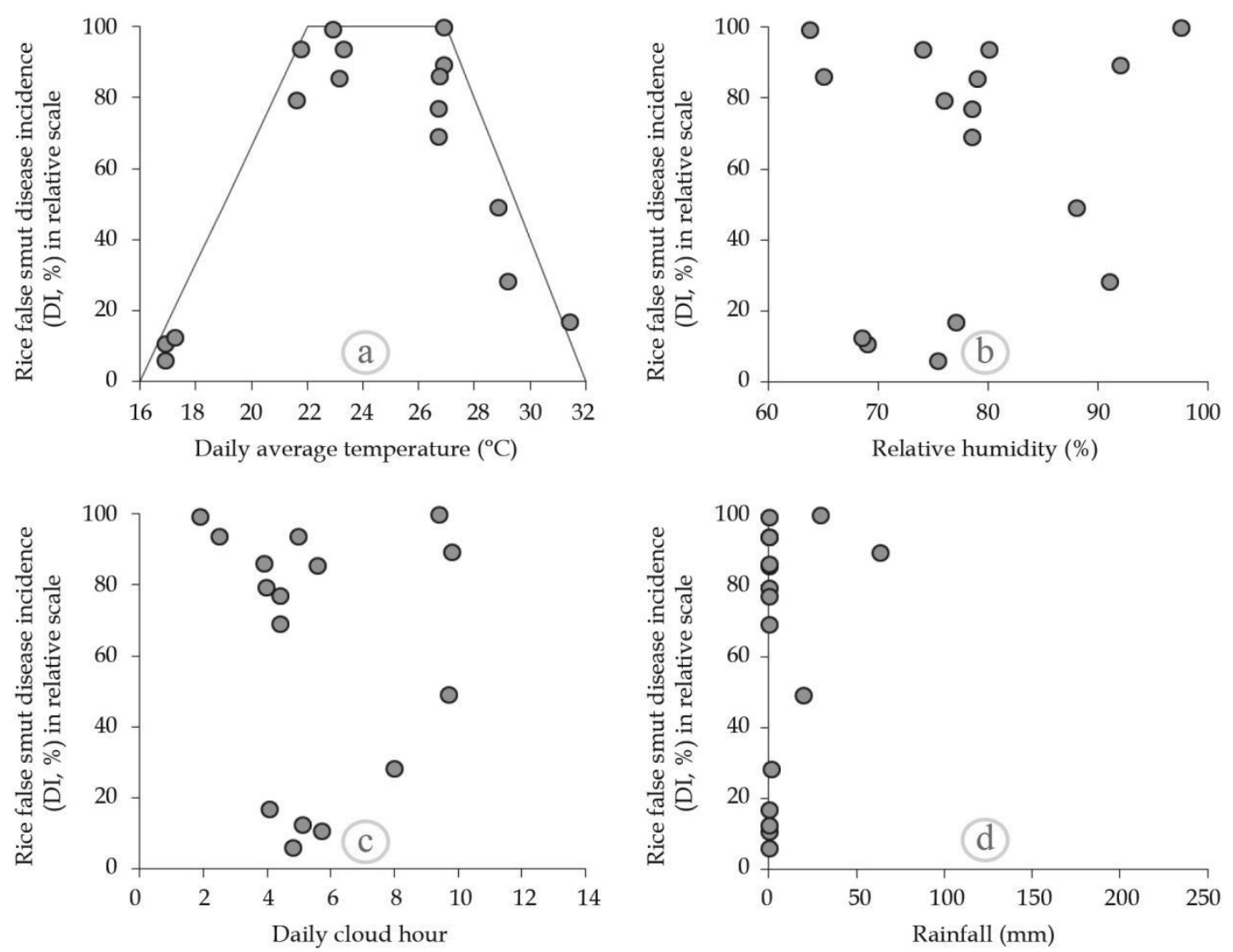

Fig. 1. Scattered diagrams showing the association of four weather variables-daily average temperature (a), relative humidity (b), cloud hours c), total rains (d) and RFSm incidence on observed 16 high disease pressure fields in the study area.

The daily average temperature during panicle emergence period showed a distinct pattern of disease incidence (Fig. 1a). Low incidence of RFSm was recorded when the average temperature was low, similarly, when it prevailed high, the disease incidence was also low. From the recorded dataset, the following relationship between daily average temperature (AvgT) at panicle emergence period and relative false smut incidence (RRFSmI) was deduced:

(i) If $16^{\circ} \mathrm{C} \leq \mathrm{AvgT} \geq 32^{\circ} \mathrm{C}$, RRFSmI $=0$

(ii) If $27 \leq \mathrm{AvgT} \geq 22, \mathrm{RRFSmI}=100$

(iii) If $\left.22^{\circ} \mathrm{C}<\operatorname{AvgT}>16^{\circ} \mathrm{C}, \mathrm{RFSmI}=100-(22-\mathrm{AvgT})^{*} \mathrm{\alpha}\right)$

(iv) If $32^{\circ} \mathrm{C}<\operatorname{AvgT}>27^{\circ} \mathrm{C}$, RRFSmI $\left.=100-(32-\operatorname{AvgT})^{*} \beta\right)$

The value of $\alpha$ and $\beta$ was calculated as 16.7 and -20 , respectively. The equations show that the incidence of RFSm did not occur when AvgT was $\leq 16^{\circ} \mathrm{C}$ or $\geq 32^{\circ} \mathrm{C}$. The incidence increased linearly with the rise of AvgT above $16^{\circ} \mathrm{C}$ till it reached to $22^{\circ} \mathrm{C}$, stayed flat up to $27^{\circ} \mathrm{C}$ and then linearly decreased till it reached to $27^{\circ} \mathrm{C}$.

\section{Variation in incidence of rice false smut disease in three seasons}

The incidence (DI) of rice false smut (RFSm) in fields in three seasons followed the sequence: T. Aman > Aus > Boro (Fig. 2). These variations were statistically significant at $95 \%$ probability level. The DI was very high in T. Aman (three years' average DI: $12.61 \pm 3.00 \%, \pm$ is $95 \%$ confidence interval) 


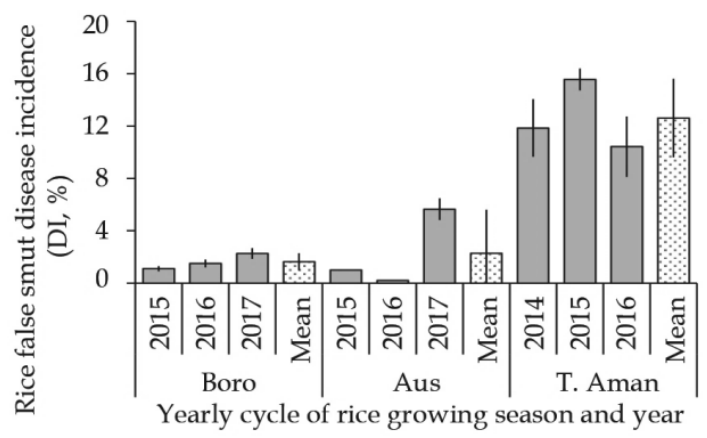

Fig. 2. The incidence (DI) of rice false smut (RFSm) disease in Boro, Aus and T. Aman seasons measured in the study area in three years. Vertical bars indicate $95 \%$ confidence level of measured fields.

compared to Aus (three years' average DI: $2.28 \pm 3.33 \%$ ) or Boro season (three years' average DI: $1.62 \pm 0.67 \%)$. In a relative scale, the RFSm incidence was potentially 8 times less in Boro and 6 times less in Aus season, compared to T. Aman season. It was noted that DI had been steadily increasing in Boro season during 2015-2017. Besides, the DI was unusually high $(5.05 \pm 0.83 \%)$ in 2017 Aus season.

The disease development: batch-by-batch smut ball formation on infected panicles

The RFSm disease appeared on infected panicles in sequence by forming new smut balls batch-by-batch. As many as eight such batches recorded in $T$. Aman season measured during mid-November to early January, three in Aus season, measured during August-September. There was variation in the DI in each batch within and between the seasons.

The final status of the disease in a field was the cumulative incidence of the batches of new smut balls formed on the crop. As shown in Fig. 3, in Aus season of 2017, the crops had 5.5 and $6.5 \%$ DI when onset of panicle emergence occurred on 14 (Sample 1) and 17 August (Sample 2) respectively. Both cases, the disease accumulated from

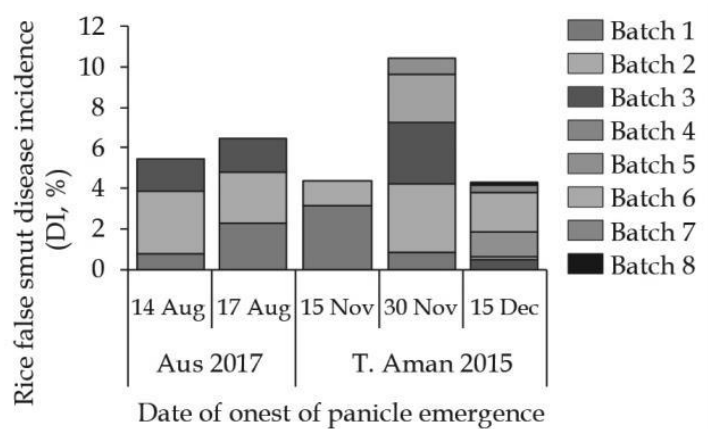

Fig. 3. Cumulative incidence (DI) of rice false smut disease through formation batches of newly formed balls on crops where panicle started to emerge on five dates 14 August, 17 August, 15 November, 30 November and 15 December.

three batches of smut balls, contributing $0.77,3.11$ and $1.58 \%$ in the 'Sample 1 ' and 2.31, 2.47 and $1.70 \%$ in the 'Sample 2'. In the T. Aman season, when onset of panicle emergence occurred on 15 November, the crop had $4.3 \%$ DI; this DI accumulated from two batches $(3.1 \%$ and $1.2 \%)$ of smut ball formation. The DI was $10.4 \%$ resulting from five batches of ball formation $(0.8,3.4,3.0$, 2.4 and $0.8 \%$ ) on the crop which had onset of panicle emergence on 30 November. The crop whose panicles started emerging on 15 December had a similar incidence of the disease $(4.3 \%)$ to the crop where panicles emergence onset on 15 November; however, the early crop (15 November panicle emerging) had two and the late crop (15 December panicle emerging) had six batches $(4.3 \%=0.5,0.2,1.1,2.0,0.3$ and $0.2 \%)$ of smut balls.

\section{DISCUSSION}

Many reports indicated high cloud cover (Ho, 1979; Ahonsi, 1995), frequent rainfall (Ho, 1979; Ahonsi, 1995; Cartwright et al. 2002; Ping et al. 2009; Fan et al. 2014) and high relative humidity (Raw, 1964; Singh, 1974; Ahonsi, 
1995; Singh et al. 1987; Hegde et al. 2000; Biswas, 2001) associated with high RFSm incidence. This study, however, did not find any such relationship. Raw (1964) observed that actual precipitation had less effect on the incidence of the disease. Dodan and Singh (1996) reported that low rainfall favoured the disease. In spore-trap experiments, it has been reported that the continuous and heavy rain can significantly decrease or even completely disappear RFSm spore-load (Sreeramulu and Vittal, 1966). With no rain at all, Devi and Singh (2007) found the highest RFSm spore concentration. In an exceptional observation, similar to this study, Bhardwaj (1990) found no correlations between disease severity and any environmental conditions during the flowering period.

This study, however, identified a characteristic pattern of similarity between RFSm incidence and average temperature during panicle emergence period. Gen et al. (2003) reported that the incidence of RFSm was significantly and positively correlated with average temperature within 15 days after heading. They inferred that the temperature was the primary climatic factor influencing the incidence of RFSm.

The present study analysed that high disease incidence occurred when the average temperature during panicle emergence period ranged between $22-27^{\circ} \mathrm{C}$; any temperature below or above the range linearly decreased the disease incidence. Literature indicates that the disease was favoured by the prevalence of lower minimum and maximum temperatures (Singh, 1974). Hegde et al. (2000) noted low maximum temperature $\left(<31^{\circ} \mathrm{C}\right)$, and high minimum temperature $\left(19^{\circ} \mathrm{C}\right)$ during $50 \%$ flowering stage were favourable for disease development. Singh et al. (1987) reported that the incidence of the disease was favoured by relatively low $\left(\sim 20^{\circ} \mathrm{C}\right)$ temperature; a similar notion was also echoed by Ho (1979). The observation of Chou (1967) showed $26-28^{\circ} \mathrm{C}$ as a suitable temperature for rice false smut. In the very recent findings, Tanaka et al. (2017) revealed that while the pathogen was present in rice plants, the development of the disease depended on meteorological conditions, where under field conditions no infection occurred at average temperature of $28^{\circ} \mathrm{C}$ and good infection was found at $25^{\circ} \mathrm{C}$. The findings of Tanaka et al. (2017) clearly support the approach of this study on designating temperature during the smut ball formation period as the key indicator for expressing the disease on a crop.

The unique climate of Bangladesh and part of India allows growing rice year-round. Bangladesh has three distinct rice seasons Boro (winter), Aus (early monsoon) and T. Aman (late monsoon). It is historically known that RFSm is a major threat to T. Aman rice in Indian subcontinent (Shetty and Shetty, 1985; BRRI, 2013), but its occurrence in other seasons remained poorly studied. This study revealed the distribution of the disease among the three seasons in the order of T. Aman > Aus > Boro; quantitatively eight and six times less in Boro and in Aus season, compared to T. Aman season. Published literature did not show any quantification on the seasonal distribution of RFSm disease.

The disease appeared on infected rice panicles in sequence through forming new balls batch by batch. More number of such batches (as many as eight) formed in T. Aman season than Aus season (recorded maximum of three batches). The final status of the disease in a crop was the accumulation of incidence of the disease in each batch. The number of batches a crop encountered dependent on the timing of appearance of the batches and the stage of the crop (termed 'crop stage') when infection could take place. This crop stage had been identified as 'late booting' in early (Ikegami, 1960) and recent (Ashizawa and Kataoka, 2005) literature. For example, this study recorded only two batches of new ball appearance in one instance, whereas six batches in the other instance. Interestingly, in 
both the instances the final disease incidence was almost the same, indicating that frequency of balls appearing in a batch could vary.

\section{CONCLUSIONS}

RFSm has the potential to infect rice yearround in Bangladesh, although it is still largely dominant in $\mathrm{T}$. Aman season. Relatively high incidence of the disease away from T. Aman such as in 2017, warrants investigation on whether variability in weather pattern responsible for altering the pattern of disease incidence in Boro and Aus seasons. The association of temperature and each batch of smut ball formation to be further investigated to ascertain the exact duration of the temperature required for symptom development.

\section{ACKNOWLEDGEMENTS}

This study was a part of the senior author's $\mathrm{PhD}$ research. The Bangladesh Agricultural Research Council (BARC) offered a PhD fellowship, and the Bangladesh Rice Research Institute (BRRI) granted study leave and provided with research facilities to run the $\mathrm{PhD}$ programme - the senior author deeply acknowledges both BARC and BRRI for that.

\section{REFERENCES}

Ahonsi, M O. 1995. Studies on the false smut of rice, Oryza sativa, induced by Ustilaginoidea virens (cke.) Tak. MS Thesis, Department of crop protection, Faculty of Agriculture, Ahmadu Bello University, Zaria, Nigeria.

Ashizawa, T, Y Kataoka. 2005. Detection of Ustilaginoidea virens in rice [Oryza sativa] panicles before and after heading in the field using nested-PCR technique with speciesspecific primers. Annals of the Phytopathological Society of Japan. 71: 16-19.
Bhardwaj, C L. 1990. False smut incidence on rice relative to plant characters and environmental factors. International Rice Research Newsletter. 15: 29-30.

Biswas, A. 2001. False smut disease of rice: a review. Environmental Biology 19: 67-83.

BRRI. 2013. Bangladesh Rice Research Institute, Adhunik Dhaner Chash (Modern Rice Cultivation). Gazipur 1701, Bangladesh (in Bangla).

Cartwright, R D, C E Parsons, B J Dodgen, F N Lee and E A Sutton. 2002. Rice disease monitoring and onfarm variety evaluation in Arkansas. In: RJ Norman and JF Meullenet (Editors), B.R. Wells Rice Research Series 2001, University of Arkansas Agricultural Experiment Station Research Series 495. Fayetteville, Ark., USA. pp. 219-228.

Chou, T G. 1967. An investigation on the occurrence of the false smut (Ustilaginoidea virens (Cooke) Takahashi) in the paddy field. Plant Protection Bulletin. 9: 51-54.

Devi, T K, I N Singh. 2007: Aerobiology and epidemiology and false smut of rice by Ustilaginoidea virens, (Syn. Clavicepsoryzae sataivae) in Thoubal district, Manipur. Journal of Mycopathological Research. 45: 107-108.

Dhaka Tribune. 2013: Jhenaidah farmers worried over smutty rice. In: Dhaka Tribune on 4 November 2013 (http://www.dhakatribune.com /agriculture/2013/nov/04/jhenaidah-farmersworried-over-smutty-rice). Accessed 2015 January 14.

Dodan, D S and R Singh. 1996. False smut of rice: present status. Agricultural Research. 17: 227-240.

Fan, J, X-Y Guo, F Huang, Y Li, Y-F Liu, L Li, Y-J Xu, J-Q Zhao, H Xiong, J-J Yu and W Wang. 2014. Epiphytic colonization of Ustilaginoidea virens on biotic and abiotic surfaces implies the widespread presence of primary inoculum for rice false smut disease. Plant Pathology. 63: 937945.

Gen, L C, ZS Y U and Y K Min. 2003. Relationships of rice false smut incidence of Liangyou Peijiu (a rice cv.) with temperature and humidity after heading. Hybrid Rice. 18: 49-52.

Hegde, Y, K H Anahosur and S Kulkarni. 2000. Influence of weather parameters on the incidence of false smut of rice. Advances in Agricultural Research in India. 14:161-165.

Ho, B L. 1979. Incidence of false smut disease of rice in relation to rice variety and climatic factors in Malaysia. MARDI Research Bulletin. 7: 89-95.

Ikegami, H. 1960. Studies on the false smut of rice, IV. Infection of the false smut due to inoculation with chlamydospores and ascospores at booting stage of rice plants. Research Bulletin Faculty of Agriculture Gifu University. 12: 45-51.

Jia Q, B Lv, M Guo, C Luo, L Zheng, T Hsiang, J Huang. 2014. Effect of rice growth stage, temperature, 
relative humidity and wetness duration on infection of rice panicles by Villosiclava virens. European Journal of Plant Pathology. 138: 763-773.

Kabir, M S, M U Salam, A Chowdhury, N M F Rahman, K M Iftekharuddaula, M S Rahman, M H Rashid, S S Dipti, A Islam, M A Latif, A K M S Islam, M M Hossain, B Nessa, M A Ali and J K Biswas. 2015. Rice Vision for Bangladesh: 2050 and Beyond. Bangladesh Rice J. 19 (2): 1-18.

Li W, L Li, A Feng, X Zhu and J Li. 2013. Rice false smut fungus, Ustilaginoidea virens, inhibits pollen germination and degrades the integuments of rice ovule. American Journal of Plant Sciences. 4: 2295-2304.

Nessa, B. 2017. Rice False Smut Disease in Bangladesh: Epidemiology, Yield Loss and Management. PhD thesis, Department of Plant Pathology and Seed Science, Sylhet Agricultural University, Sylhet, Bangladesh.

Nessa, B, M U Salam, A H M M Haque, J K Biswas, W J MacLeod, M A Ali, K P Halder and J Galloway. 2015a. FLYER: A simple yet robust model for estimating yield loss from rice false smut disease (Ustilaginoidea virens). Am J Agric Biol Sci. 10 (1): 41 - 54.

Nessa, B, M U Salam, A H M M Haque, J K Biswas, M S Kabir, W J MacLeod, M D'Antuono, H N Barman, M A Latif and J Galloway. 2015b. Spatial pattern of natural spread of rice false smut (Ustilaginoidea virens) disease in fields. Am. J. Agric. Biol. Sci. 10: 63-73.

Nessa, B, M U Salam, A H M M Haque, J K Biswas, M A Latif, M A Ali, T H Ansari, M Ahmed, N Parvin, M Z I Baki, S Islam, MS Islam and J Galloway. 2015c. Rice false smut disease at different flowering times. Bangladesh Rice J. 19 (2): 29-35.

Nessa, B, M U Salam, A H M M Haque, J K Biswas, Q S A Jahan, M A I Khan, M R Bhuiyan, A Ara, M R
Munir, J Galloway, M S Kabir and M A Ali. 2016. Density and distribution of false smut balls on infected rice panicles. Bangladesh Rice J. 20 (2): 73-79.

Nessa, B, S S Dipti, M U Salam, A H M M Haque, J K Biswas, M A Kashem and M S Kabir. 2018. Seed and grain quality of rice as affected by false smut disease. Bangladesh Rice J. 22 (1): 1-7.

Ping, L J, T Tao, Z S Bai, Z H Bin. 2009. Preliminary studies on initial infection sources and pathogen-infecting favourable stage for rice false smut. Hybrid Rice. 24: 74-77.

Raw, K M. 1964. Environmental conditions and false smut incidence in rice. Indian Phytopathology. 17: 110114.

Shetty, S A, H S Shetty. 1985. A hitherto unrecorded collateral host of Ustilaginoidea virens (Cke) Tak. Current Science. 54: 646-647.

Singh, R A. 1974. Meteorological factors influencing the occurrence of false-smut of rice. Indian Journal of Agricultural Science. 44: 718-721.

Singh, G P, R N Singh and A Singh. 1987. Status of false smut (FS) of rice in eastern Uttar Pradesh, India. International Rice Research Newsletter. 12: 28.

Sreeramulu, T and B P R Vittal. 1966. Periodicity in the air-borne spores of the rice false smut fungus, Ustilaginoidea virens. Transaction of British Mycology Society. 49: 443-449.

Tanaka, E, T Kumagawa, N Ito, A Nakanishi, Y Ohta, E Suzuki, N Adachi, A Hamada, T Ashizawa, T Ohara and M Tsuda. 2017. Colonization of the vegetative stage of rice plants by the false smut fungus Villosiclava virens, as revealed by a combination of species-specific detection methods. Plant Pathology. 66: 56-66.

Webster, R K and P S Gunnell. 1992. Compendium of Rice Diseases. American Phytopathological Society, St. Paul, Minnesota, USA. 